\title{
Holocene Soil Evolution in South Siberia Based on Phytolith Records and Genetic Soil Analysis (Russia)
}

\author{
Denis A. Gavrilov ${ }^{1, * \mathbb{D}}$, Sergey V. Loiko ${ }^{2}$ and Nina V. Klimova ${ }^{3}$ \\ 1 Laboratory of Soil Genesis and Geography, Institute of Soil Science and Agrochemistry, \\ Siberian Branch of the Russian Academy of Sciences, 630090 Novosibirsk, Russia \\ 2 BIO-GEO-CLIM Laboratory, National Tomsk State University, 634050 Tomsk, Russia; s.loyko@yandex.ru \\ 3 Laboratory for Forest Ecosystem Monitoring, Institute of Monitoring of Climatic and Ecological Systems, \\ Siberian Branch of the Russian Academy of Sciences, 634055 Tomsk, Russia; klimnin@sibmail.com \\ * Correspondence: gavrilov@issa-siberia.ru; Tel.: +7-383-363-90-30
}

Received: 20 September 2018; Accepted: 1 November 2018; Published: 5 November 2018

check for updates

\begin{abstract}
Dark, coniferous hemiboreal forests in the south of West Siberia are located in the Holocene forest-steppe ecotone, where natural environmental conditions have been quite dynamic. This dynamic environment resulted in the contrasting evolution of regional soil cover and the development of unique soil profiles with the second humus horizon. The second humus horizon is assumed to be a relic from the dark-humus soil formation stage in the mid-Holocene. This article draws conclusions about changes in regional environmental conditions by analysing data from a geochemically interrelated coevolutionary soil series, obtained by using a combination of conventional soil studies, phytolith analyses, and accelerator mass spectrometry (AMS) dating of phytolith-occluded carbon (PhytOC) and humic acids. The results showed that, in general, phytocenoses changed from mire-meadow vegetation towards forest vegetation via the meadow stage. However, these stages had different durations, depending on the soil catenary position. The topographical divergence of soil phytolith profiles reflects the relief effect on the development of specific soil type combinations, accounting for the major elements of the regional mid-Holocene soil cover. The leading elementary soil-forming processes were humus accumulation and hydrogenic accumulation of calcium carbonates. In the hilltop site of Endocalcic Stagnic Albic Luvisols, the evolutionary changes were shown by the shift from the meadow phytocenosis (Calcic Stagnic Chernozem) to the forest phytocenosis. In the midslope site, the environment was more humid from the start, favouring a phytocenosis with features of the meadow-mire type. The shift from the meadow-mire environment (with Spodic Chernic Gleysols) to the forest type environment with leading profile-forming processes, acid hydrolysis and lessivage, was gradual, occurring via the meadow stage with Calcic Stagnic Chernozem. In the toeslope site (Calcic Stagnic Greyzemic Epidystric Umbrisols), the meadow-mire stage (with Spodic Chernic Gleysols) was succeeded by the forest stage of soil formation. The AMS-dating of PhytOC estimated that the dark-humus stage of soil formation began 6.5-5.7 years calBC. Despite the observed slight translocation of phytoliths down soil profiles and phytolith solubilisation, phytolith analysis can be used to reconstruct shifts in the soil formation environment for surface Holocene palaeosols.
\end{abstract}

Keywords: soil evolution; phytolith; AMS-dating; PhytOC; West Siberia; paleoenvironment

\section{Introduction}

Dark, coniferous hemiboreal forests (Milio effusi-Abietetea sibiricae) $[1,2]$ are common in the southern taiga subzone within the West Siberian Plain, where they grow on automorphic, texturally differentiated, and semihydromorphic organic matter accumulating soils that often have residual 
humus horizons [3-5]. Such forests are spread throughout the Holocene forest-steppe ecotone, and dynamic changes in the geographic environment of the ecotone in the past have resulted in the complex and contrasting evolution of its soils and soil cover. In the mid-Holocene, the soils of the forest-steppe ecotone underwent the dark-humus stage of soil formation, which was later succeeded by the active textural differentiation of automorphic soils and the hydrogenic transformation of soils on the margins of the increasing mires. Due to all these processes, mineral soils of the region display polygenetic features, recorded in the complex structure of their organic matter profiles. These include high humus content, differences in humus quality between the contemporary and the second humus horizons, occurrence of molecasts, residual solonetz, carbonates, and solodic features.

Diversity of the soil morphology, resulting from combined modern and relic features, has led to much discussion on the origin of the soil. The most heated discussions concern the second humus horizon and its residual high humus content. Presently, there exist two conflicting hypotheses: (1) The actualistic hypothesis, which considers the complexity of the organic matter profile to be the result of the illuviation of humic acids at the border between eluvial and illuvial layers [5,6]; and (2) the historico-evolutionary hypothesis, which considers the second humus horizon and its residual high humus content to be relic features of the earlier dark-humus soil formation stage of the Holocene ([3,4,7-12], and other). The latter hypothesis is currently the most widely accepted and has been confirmed by a series of humic acid radiocarbon dating that was obtained from the second humus horizon with modal dates of 4000-5000 year with the oldest being 6000-7000 year [13,14].

Soils with complex organic matter profiles may occupy different meso- and microrelief positions, each of which influences the morphology of the second humus horizon in a number of ways, i.e., their depth, thickness, colour, and patchiness. In addition, the topogeny in the mid-Holocene also determined the specific soil formation environment, a fact which was noted already in the second half of the last century $[3,11]$; however, further consideration of this aspect of the second humus horizon genesis has not obtained proper scientific consideration.

Thus, the diversity of soil polygenetic profiles and the differing views on their evolution necessitate additional studies with new techniques that will either confirm or contradict these hypotheses. Phytolith analysis is one such technique that has been increasingly employed in soil research for morphological and genetic analyses [15-26]. The relatively weak migration capability of phytoliths in a landscape [27-29], and allows correlational study between phytolith assemblages and soil properties that reflect specific soil formation environments. Additionally, the combined use of phytolith and soil analyses provides the opportunity to study soil development due to catena positions. Employing only early methods to study complex organic matter profiles, i.e., humus structure and composition, soil micromorphology, and carbonate profiles, does not always provide unequivocal answers about the environmental conditions that favoured the development of their complex profiles, as second humus horizons display different degrees of degradation.

Therefore, to study the evolutionary peculiarities of soils with complex organic matter profiles within a geochemically dependent soil series of the Vasyugan sloping plain in the south of West Siberia, we used a set of morphological, genetic, physical, and chemical methods, as well as phytolith analysis. In addition, we aimed to: (1) Assess the possibility of using phytoliths to determine the time of the organic matter accumulation stage of soil formation in comparison with humic acids; (2) estimate the temporal sustainability of soil phytolith profiles compared to the profile distribution of other characteristics, such as humus content, carbonate content, etc.; and (3) reconstruct soil cover during the regional Holocene optimum using polygenetic soils situated on the same catena.

\section{Materials and Methods}

\subsection{Soil Sampling}

A series of pits in texturally differentiated and organic matter accumulating soils were dug along a microcatena from the hilltop down to the toeslope sites on the sloping hilly transition between the 
watershed and the Iksa riverbed ( $58^{\circ} 44^{\prime} 04^{\prime \prime} \mathrm{N}, 68^{\circ} 50^{\prime} 52^{\prime \prime} \mathrm{E}$, Bakchar district, Tomsk region, Russia). The microcatena was $80 \mathrm{~m}$ long with a $0.2 \%$ incline (Figure 1 ).

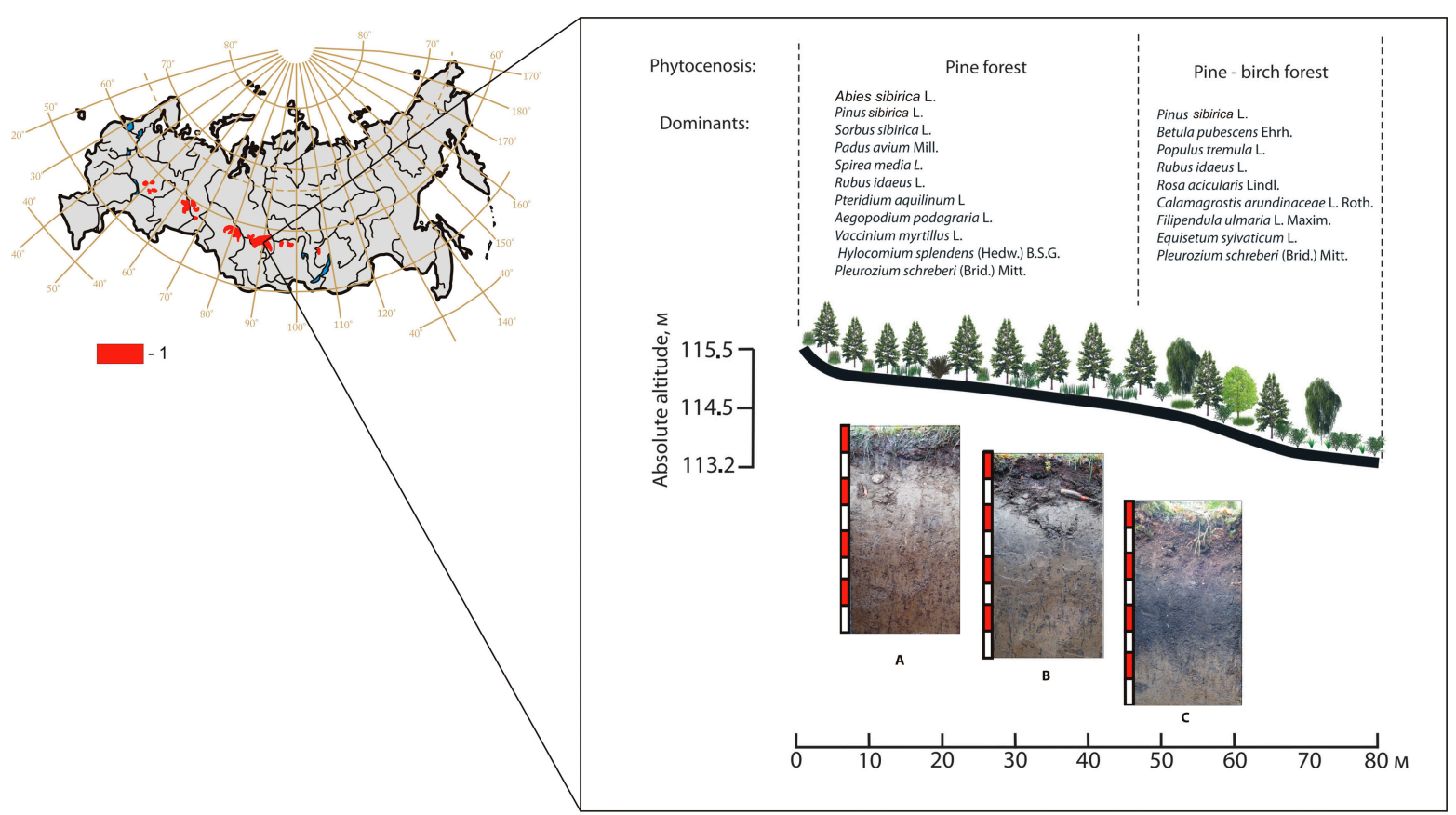

Figure 1. Schematic presentation of the catena studied. Vegetation composition and polygenetic soils with the second humus horizon on the study sites on the Vasyugan sloping plain: A-Endocalcic Stagnic Albic Luvisols (Siltic, Abruptic, Cutanic, Epiloamic) on the hilltop; B-Endocalcic Stagnic Albic Luvisols (Siltic, Abruptic, Cutanic, Epiloamic) in the midslope; C-Calcic Stagnic Greyzemic Epidystric Umbrisols (Siltic) on the toeslope. A pit displaying the eluvial part and the upper portion of the illuvial layer (below the lower border of the second humus horizon, with no explicit features of windfall phenomena) was dug on both catena positions. 1-Soils with the second humus horizon [30].

Pits displaying the eluvial part and the upper portion of the illuvial layer (below the lower border of the second humus horizon, with no explicit features of windfall phenomena) were dug on both catena positions.

Soil for physical and chemical analyses was sampled every $5-10 \mathrm{~cm}$ by continuous coring through soil genetic horizons, while phytolith analysis samples were taken from the lower $1-2 \mathrm{~cm}$ of each $5 \mathrm{~cm}$ soil horizons [31].

For radiocarbon dating, soil samples were collected from a $1 \mathrm{~cm}$ thick layer at the upper and lower borders of E, Eh, and $\mathrm{A}^{\prime}$ in each soil pit.

\subsubsection{Hillltop and Midslope Catena Sites}

In the hilltop and midslope catena sites, soils are represented by Endocalcic Stagnic Albic Luvisols (Siltic, Abruptic, Cutanic, Epiloamic) within the second humus horizon [32]. The sites are covered by fir and pine (Abies sibirica L. and Pinus sibirica L.) forest with an understorey of Sorbus sibirica L. and Padus avium Mill., and a ground cover of herbs and green mosses. Shrubs are represented by Spirea media L. and Rubus idaeus L. Projective cover of the shrubs and herbs story was ca. 60\%, being dominated by Pteridium aquilinum L., Aegopodium podagraria L., and Vaccinium myrtillus L. The mosses were dominated by the green mosses, Hylocomium splendens (Hedw.) B.S.G. and Pleurozium schreberi (Brid.) Mitt.

\subsubsection{Toeslope Catena Site}

In the toeslope site, the soil is represented by Calcic Stagnic Greyzemic Epidystric Umbrisols (Siltic) under pine (Pinus sibirica L.) and birch (Betula pubescens Ehrh.) forest with some aspen (Populus 
tremula L.) and no understory. The shrubs are well developed, consisting of Rubus idaeus L. and Rosa acicularis Lindl. Projective cover of the herbaceous storey was ca. 50\%, with Calamagrostis arundinaceae L. Roth., Filipendula ulmaria L. Maxim., and Equisetum sylvaticum L. dominating. The story of lichen and mosses is poorly developed, being represented by Pleurozium schreberi (Brid.) Mitt.

\subsection{Methods}

\subsubsection{Morphologic and Genetic Analyses}

During the field work, the morphology of the studied soils was described following the Guidelines for soil description [33], and soils were identified according to the World Reference Base (WRB) classification [32].

\subsubsection{Physical and Chemical Analyses}

Particle-size analysis of soil samples was determined by the pipette method after preliminary treatment of soil with a $4 \% \mathrm{Na}_{4} \mathrm{P}_{2} \mathrm{O}_{7}$ solution [34] (The fraction limits were established following Kachinskiy [34]. These limits are rather similar to those of WRB [32], the only discrepancy in the limits of the clay fraction, i.e., $0.001 \mathrm{~mm}$ according to Kachinskiy and $0.002 \mathrm{~mm}$ according to the WRB, does not seem to be very significant).

Soil organic matter carbon (SOC) was determined by the dichromate redox titration method [35]. Exchangeable cation content $\left(\mathrm{Ca}^{+2}, \mathrm{Mg}^{+2}, \mathrm{~K}^{+}, \mathrm{Na}^{+}\right)$was estimated by using $1 \mathrm{M} \mathrm{NH}_{4} \mathrm{Oac}$ for extraction [36], and exchange hydrogen $\left(\mathrm{H}^{+}\right)$was measured in $1 \mathrm{M} \mathrm{BaCl}_{2}$ extracts titrated with $0.02 \mathrm{M}$ $\mathrm{NaOH}$ [37]. Soil reaction and $\mathrm{CaCO}_{3}$ were measured according to Hendershot et al. [36].

The studied soils had heavy or light loamy particle size composition with sharply differentiated textural profiles and a slight difference in silt differentiation coefficients.

\subsubsection{Accelerator Mass Spectrometry ${ }^{14} \mathrm{C}$ Dating of Humic Acids (II) and Phytolith-Occluded Carbon}

The calcium-free humic acid fraction II (HAII) was prepared following the protocol described by O. Chichagova [38].

Phytoliths for ${ }^{14} \mathrm{C}$-dating were prepared according to the slightly modified method of $\mathrm{X}$. Zuo et al. [39]. The detailed steps were as follows: (a) Dry soil was crushed and sieved at $500 \mu \mathrm{m}$; (b) the sample was deflocculated with $4 \% \mathrm{Na}_{5} \mathrm{P}_{3} \mathrm{O}_{10}$, and then washed three to four times with distilled water; (c) organic matter was first oxidised by $250 \mathrm{~mL}$ of $\mathrm{H}_{2} \mathrm{O}_{2}$ (30\%) for $12 \mathrm{~h}$ at room temperature and then heated in a water bath until the reaction stopped; $d$ ) carbonates were eliminated using $200 \mathrm{~mL}$ of $\mathrm{HCl}(10 \%)$ with heating for $30 \mathrm{~min}$; (d) the $>250 \mu \mathrm{m}$ fraction was separated by wet sieving, and the remaining sample was disaggregated from the organic material and clay by ultrasonic treatment for $20 \mathrm{~min}$; (f) clays $(<5 \mu \mathrm{m})$ were removed by gravity sedimentation until the sample was clear (2-3 month); and (g) any remnant organic material was removed by digestion using "Schulzes Solution". $50 \mathrm{~mL} \mathrm{KClO} 3$ was added to $250 \mathrm{~mL}$ of $\mathrm{HNO}_{3}$ to make this highly corrosive cocktail. About $30 \mathrm{~mL}$ of the solution was added to the test tubes containing the sample and digestion carried out in a water bath $\left(80^{\circ} \mathrm{C}\right)$ in a fume cupboard. Distilled water was added to the sample, and this was centrifuged for $5 \mathrm{~min}$ at $5000 \mathrm{rpm}$. This procedure was repeated three times to clean the sample of any remaining solution. (h) Phytoliths were extracted three times by $200 \mathrm{~mL}$ of heavy liquid (CdI $+\mathrm{KI}$ ) with a specific density of $2.35 \mathrm{~g} / \mathrm{cm}^{3}$ and then washed three times with distilled water; (i) extracted phytoliths were further sieved at the track membrane with pore of $5 \mu \mathrm{m}$ to remove clay. Then, the recovered part of the remains in the sieve were treated by $20 \mathrm{~mL}$ of $\mathrm{H}_{2} \mathrm{O}_{2}(30 \%)$ in the tube for $20 \mathrm{~min}$. (j) Finally, the recovered phytoliths were dried at $60^{\circ} \mathrm{C}$ for $24 \mathrm{~h}$ prior to testing.

The purity of the phytoliths was checked by optical microscope (X400) and SEM-EDS analysis. In this study, the extracted phytoliths were analysed using an SEM (JEOL 6610 LV, Tokyo, Japan) in association with an EDS (Energy Dispersive Spectroscopy) system (INCAWave, SEM, Tokyo, Japan). 
Graphite was obtained from phytolith concentrate in which the ${ }^{14} \mathrm{C}$ isotope content was measured using the CAIS $0.5 \mathrm{MeV}$ accelerator of the SB RAS Core Facility "Cenozoic Geochronology" (Novosibirsk, Russia) and of the Center for Applied Isotope Studies, University of Georgia (Athens, GA, USA). The radiocarbon dates were calibrated using the OxCal v4.3 software [40] and the IntCal 13 calibration curve.

Carbon content of humic acid and phytolith preparations was determined using the elemental analyser, Euro EA 3028 HT, Eurovector (Milan, Italy).

\subsubsection{Phytolith Analysis: Procedure and Interpretation}

Samples for phytolith analysis were dried and subjected to standard procedures [41]. After treatment with a hot $30 \% \mathrm{H}_{2} \mathrm{O}_{2}$ solution and $10 \% \mathrm{HCl}$, samples (approximately $50 \mathrm{~g}$ ) were separated from sand and clay, and subjected to flotation in heavy liquid (cadmium iodide and potassium iodide solution with a gravity of approximately 2.3). After centrifugation ( $1500 \mathrm{r} / \mathrm{min}$ for $20 \mathrm{~min}$ ), the floating phytoliths were collected in a tube, washed several times with distilled water, and studied under an optical microscope with $300 \times$ magnification [41]. Phytoliths were counted for the cover glass $(24 \mathrm{~mm} \times 24 \mathrm{~mm})$ area.

Phytolith analyses data were interpreted according to the methodology proposed by A.A. Golyeva $[18,31,42,43]$. The authors identified a special type of soil profile-the phytolith profile-which is on par with other profiles (humus, carbonate, texture, etc.).

A phytolith profile develops during the entire soil life span, recording changes in the environment, soil-forming factors, or anthropogenic impacts in its qualitative and quantitative characteristics. Changes in soil-forming conditions and in phytocoenosis properties lead to the gradual replacement of one phytolith profile with a new one, but the general stratigraphic regularity of the phytolith persists, i.e., the deeper samples are older than the ones closer to the current soil surface.

To describe phytolith forms, we used the Code for Phytolith Nomenclature 1.0 [44], and then grouped the forms into diagnostic assemblages according to A. Golyeva [18,31,42,43]: The universal phytolith forms do not allow identification of plants below the class level of Dicotyledoneae; several ecological assemblages specific for certain phytocoenoses, such as taiga, meadow, steppe, or dry steppe; and phytolith forms that are specific for some families, e.g., Cyperaceae, Pinaceae, or species, e.g., Phragmites spp., called "signal forms" by some researchers [31].

\subsubsection{Preservation of Some Features of the Dark-Humus Stage of Soil Formation}

Reconstructing soil-forming conditions and soil evolution on the basis of the properties of modern polygenetic soils presents certain methodological difficulties. Soil as an "open-closed" system is constantly exchanging energy and matter with its environment, thus compromising its relic features. Those features that are preserved represent fragments of the indigenous profile that has been transformed. Analysis of such transformation is indispensable for the studies of polygenetic soils.

The catena soils in our study are heterogenic and quite synchronic in origin, which implies their co-evolution. This circumstance allows for the assessment of the sustainability of soil features resulting from the dark-humus accumulation stage of soil formation due to the relief distribution of energy and matter flows.

Increasing textural differentiation of soils from the toeslope to the hilltop sites is the main factor limiting changes in the second humus horizons, such as decreased thickness, colouration, and spread, intrapedic mass structure, and certain other properties.

\section{Results and Discussion}

\subsection{Soil Morphology and Genesis}

Field examination of soil profiles and morphology revealed different thicknesses of albic material and textural differentiation of soil profiles in all catena sites (Table 1). However, the morphological 
traits of the processes seemed to be expressed differently depending on the relief (Figure 1), as textural differentiation is most pronounced on the hilltop and less pronounced on the toeslope.

Table 1. Field description of soils.

\begin{tabular}{|c|c|c|}
\hline Horizon & Depth, cm & Field Morphological Description \\
\hline \multicolumn{3}{|c|}{ Endocalcic Stagnic Albic Luvisols (Siltic, Abruptic, Cutanic, Epiloamic) (L1, hilltop) } \\
\hline $\mathrm{O}$ & $0-7$ & $\begin{array}{l}\text { Peat-like litter of semi-decomposed needles, cones, standing dead phytomass; } \\
\text { brown-coloured, loose, fresh, with sharp transition, the boundary having } \\
\text { small waves. }\end{array}$ \\
\hline A & $7-13$ & $\begin{array}{l}\text { Brown-grey in colour, silt loam, loose, small lumps, with plenty of plant roots; } \\
\text { the boundary is clear, with some waves and tongues. }\end{array}$ \\
\hline $\mathrm{E}$ & $13-30$ & $\begin{array}{l}\text { Light grey with a brown shadow, fresh, slightly packed, silt, foliaceous, with } \\
\text { plenty of plant roots, clear wavy boundary. }\end{array}$ \\
\hline Eh & $30-40$ & $\begin{array}{l}\text { Light grey with separate grey humus spots, fresh, silt loam, foliaceous, transition } \\
\text { into the lower horizon is gradual, wavy boundary. }\end{array}$ \\
\hline Btst & $40-70$ & $\begin{array}{l}\text { Brown-coloured with dark grey humus tongues, moist, silty clay, lumpy, humus } \\
\text { cutans on ped edges, gradual transition, wavy boundary. }\end{array}$ \\
\hline Btk & $70-80$ & $\begin{array}{l}\text { Brown-coloured with dark grey humus tongues, moist, silty clay, lumpy, humus } \\
\text { cutans on ped edges, gradual transition, carbonated from } 55 \mathrm{~cm} \text { and deeper. }\end{array}$ \\
\hline \multicolumn{3}{|c|}{ Endocalcic Stagnic Albic Luvisols (Siltic, Abruptic, Cutanic, Epiloamic) (L2, midslope) } \\
\hline $\mathrm{O}$ & $0-6$ & $\begin{array}{l}\text { Peat-like litter of semi-decomposed needles, cones, aboveground dead } \\
\text { phytomass. Brown-coloured, loose, fresh, with sharp transition, boundary with } \\
\text { small waves. }\end{array}$ \\
\hline $\mathrm{A}$ & $6-13$ & $\begin{array}{l}\text { Light grey, fresh, silt loam, loose, small lumps, plentiful plant roots, clear } \\
\text { transition, boundary with mid-sized waves. }\end{array}$ \\
\hline $\mathrm{E}$ & $13-24$ & $\begin{array}{l}\text { Light grey with a brown shadow, fresh, weakly packed, silt loam, silty, porous, } \\
\text { foliaceous, with plentiful plant roots, noticeable transition, boundary with } \\
\text { small waves. }\end{array}$ \\
\hline $\mathrm{A}^{\prime}$ & $24-42$ & $\begin{array}{l}\text { Dark grey, fresh, silt clay loam, granular-lamellar, packed, transformed by } \\
\text { earthworm passages, gradual transition, boundary with mid-sized waves. }\end{array}$ \\
\hline Bt, st & $42-70$ & $\begin{array}{l}\text { Brown-coloured with dark grey humus tongues, moist, silty clay, lumpy-nutty, } \\
\text { humus cutans on ped edges, gradual transition, wavy boundary. }\end{array}$ \\
\hline Btgk & $70-80$ & $\begin{array}{l}\text { Brown-coloured with dark grey humus tongues, grey-bluish spots, moist, silty } \\
\text { clay, tabular, carbonated (white eye), humus cutans on ped edges, gleyic. }\end{array}$ \\
\hline \multicolumn{3}{|r|}{ Calcic Stagnic Greyzemic Epidystric Umbrisols (Siltic) (St, toeslsope) } \\
\hline $\mathrm{O}$ & $0-10$ & $\begin{array}{l}\text { Peat-like litter of semi-decomposed needles, cones, aboveground dead } \\
\text { phytomass; brown, loose, fresh, sharp transition, boundary with } \\
\text { middle-sized waves. }\end{array}$ \\
\hline A & $10-24$ & $\begin{array}{l}\text { Light grey with dark grey patches, fresh, loose, silt clay loam, small granules, } \\
\text { plentiful plant roots, noticeable transition, boundary with mid-sized waves. }\end{array}$ \\
\hline $\mathrm{A}^{\prime}$ & $24-50$ & $\begin{array}{l}\text { Dark grey, moist, silty clay loam/silty clay, granular, packed, with solitary plant } \\
\text { roots, clear transition, boundary with small-sized waves. }\end{array}$ \\
\hline $\mathrm{A}^{\prime} / \mathrm{Bg}$ & $50-70$ & $\begin{array}{l}\text { Brown-coloured with dark grey humus tongues, silty clay, moist, curdled, } \\
\text { ferrous, gradual transition, boundary with tongues. }\end{array}$ \\
\hline Bstk & $70-85$ & $\begin{array}{l}\text { Brown-coloured with some morphons filled with humus material (speckled) and } \\
\text { grey-bluish and ochre spots, moist, silty clay, curdled, carbonated. }\end{array}$ \\
\hline
\end{tabular}

There were also signs of the gradual degradation of the upper part of the second humus horizon due to the albic material forming, which is displayed by introduction of fragments of whitish material from the E horizon into the dark-coloured material of the Eh and $\mathrm{A}^{\prime}$ horizons. 
On the hilltop, the second humus horizon (Eh) is the most degraded and could be seen as the dark-grey patches on a $10 \mathrm{~cm}$ thick light-grey background with a foliar structure. In the midslope and toeslope sites, the second humus horizon $\left(\mathrm{A}^{\prime}\right)$ was much better expressed morphologically, as a black-coloured continuous $25 \mathrm{~cm}$ thick horizon with a grainy microstructure.

The morphology of the second humus horizon on the midslope, i.e., its similar colouration and structure, allows the conclusion that humus accumulation was the leading elementary soil process, resulting in the development of the specific soil profile. A large $(40-60 \mathrm{~cm})$ portion of the humus horizon, currently registered in the soil profile as the humus-eluvial layer, suggests a quasi-equilibrium state between already well-developed, mature soils and their soil-forming factors at the start of textural differentiation.

Thus, the soils of the studied catena have a polygenetic structure and can be considered the relics of the main regional soil types of the optimum Holocene soil cover.

\subsection{Soil Physical and Chemical Properties}

The Endocalcic Stagnic Albic Luvisols had an accumulative distribution of $\mathrm{H}^{+}$cations, and a progressively eluvial distribution of $\mathrm{Ca}^{2+}$ (Table 2).

The contribution of exchangeable $\mathrm{Ca}^{2+}$ into the total sum of exchangeable cations in the upper soil profile was lower in the hilltop site compared to the midslope site. Exchangeable $\mathrm{Mg}^{2+}$ was shown to have an eluvial-illuvial profile distribution. Sodium cations were also found to contribute to the cation-exchange soil complex $\left(0.5-0.6 \mathrm{Cmol} \mathrm{kg}^{-1}\right)$. The studied Endocalcic Stagnic Albic Luvisols were shown to have contrasting acidity, as the upper $70-80 \mathrm{~cm}$ of the soil profile had an acidic reaction $(\mathrm{pH}$ $\mathrm{H}_{2} \mathrm{O}$ 4.1-6.7), which became more neutral, and even alkaline, with increasing depth $\left(\mathrm{pH} \mathrm{H}_{2} \mathrm{O}\right.$ 7.0-8.1). Below $70-80 \mathrm{~cm}$, the upper border of the high carbonate content, which reached $5 \%$, was found.

Calcic Stagnic Greyzemic Epidystric Umbrisols with the second humus horizon occupied the toeslope site of the catena. This soil exists in both acidic and alkali conditions. The upper profile, i.e., the Aq horizon, is under the influence of acidic solutions reaching it from the acidic forest litter ( $\mathrm{pH} \mathrm{H}_{2} \mathrm{O}$ 4.2-6.3), whereas in the lower profile, i.e., the $\mathrm{A}^{\prime}$ and Bgk horizons, the soil reaction is neutral or even alkaline ( $\left.\mathrm{pH} \mathrm{H} \mathrm{H}_{2} \mathrm{O} 7.0-8.2\right)$.

Exchangeable $\mathrm{Ca}^{+2}$ was found to be $16-22 \mathrm{Cmol} \mathrm{kg}^{-1}$, while the $\mathrm{H}^{+}$contribution was small, but, nevertheless, could be traced down to the $\mathrm{B}$ horizon. Exchangeable $\mathrm{Na}^{+}$was found to range within $0.7-0.8 \mathrm{Cmol} \mathrm{kg}^{-1}$. The result of particle-size analysis showed that the soil had silty clay loam/silty clay composition (Table 2). Soil organic $C$ showed an accumulative profile distribution pattern, with a maximum (3\%) in the A horizon and a gradual decrease below the $\mathrm{A}^{\prime}$ horizon upper limit $(1 \%)$ and further down to the B horizon $(0.3 \%)$. The B horizon contained few carbonates $(>0.4 \%)$ that were detected only below $70 \mathrm{~cm}$.

Physical and Chemical Properties Preserved from the Dark-Humus Stage of Soil Formation

Soil organic $\mathrm{C}$ properties strongly reflected the degradation of the second humus horizon, as the SOC profile distribution was found to change depending on clay illuviation and thickness of the albic material (Table 2). Maximal and minimal second humus horizon degradation was found in the hilltop and toeslope sites studied, respectively; the SOC profile distribution had an accumulating pattern in the hilltop and the toeslope positions, reaching, in the A horizon, $1.9 \%$ and $3.0 \%$, respectively. In the midslope site, the soil SOC profile showed a regressively accumulating pattern with relative maxima in the A and A' horizons, which suggests this soil is an intermediary variant of the degradation of the dark-humus soil formation stage.

The presence of carbonate concretia in the Bt and B horizons, in combination with a high degree of CEC saturation (Dystrict), suggests that carbonates in the soil represent a relic property, i.e., a residual from the previous soil formation stage with a predominant transpiration water regime (Tables 1 and 2). Following humus profiles, soil carbonate profiles experienced significant changes; however, despite the latter, these profiles represent solid evidence of additional water inflow of the soils in the past. 
Table 2. Soil chemical and physical properties.

\begin{tabular}{|c|c|c|c|c|c|c|c|c|c|c|c|c|c|c|c|}
\hline \multirow{3}{*}{ Horizon } & \multirow{3}{*}{$n^{2}$} & \multirow{3}{*}{ Depth, cm } & \multirow{3}{*}{$\mathrm{SOC}^{3}, \%$} & \multicolumn{2}{|c|}{$\mathrm{pH}$} & \multirow{3}{*}{$\mathrm{CaCO}_{3}, \%$} & \multicolumn{5}{|c|}{ Exchangeable Cations } & \multicolumn{4}{|c|}{ Soil Texture } \\
\hline & & & & \multirow{2}{*}{$\mathrm{H}_{2} \mathrm{O}$} & \multirow{2}{*}{$\mathrm{KCl}$} & & $\mathrm{H}^{+}$ & $\mathrm{Ca}^{2+}$ & $\mathrm{Mg}^{2+}$ & $\mathrm{Na}^{+}$ & $\mathrm{K}^{+}$ & Sand & Clay & Silt & \multirow{2}{*}{ Classes } \\
\hline & & & & & & & \multicolumn{5}{|c|}{$\mathrm{Cmol} \mathrm{kg}^{-1}$} & \multicolumn{3}{|c|}{$\%$} & \\
\hline \multicolumn{16}{|c|}{ Endocalcic Stagnic Albic Luvisols (Siltic, Abruptic, Cutanic, Epiloamic) (L1, hilltop) } \\
\hline A & 1 & $7-13$ & 1.9 & 4.1 & 3.1 & 0 & 22.4 & 3.1 & 0.9 & 0.5 & 1.3 & 10.6 & 14.1 & 75.3 & Silt Loam \\
\hline $\mathrm{E}$ & 2 & $13-30$ & 0.5 & $4.4 \pm 0.3$ & $3.2 \pm 0.1$ & 0 & $7.4 \pm 0.7$ & $3.1 \pm 0.0$ & $0.9 \pm 0.0$ & 0.4 & $0.8 \pm 0.5$ & $6.3 \pm 0.9$ & $11.6 \pm 1.7$ & $82.1 \pm 0.8$ & Silt \\
\hline Eh & 1 & $30-40$ & 0.5 & 5.1 & 3.4 & 0 & 6.3 & 10.5 & 3.9 & 0.5 & 0.6 & 3.0 & 25.6 & 71.4 & Silt Loam \\
\hline $\mathrm{Bt}$ & 4 & $40-70$ & $0.3 \pm 0.11$ & $6.8 \pm 1.1$ & $5.2 \pm 0.9$ & $0.2 \pm 0.2$ & $3.1 \pm 1.7$ & $20.6 \pm 1.3$ & $10 \pm 1.0$ & 0.6 & $0.9 \pm 0.1$ & $2.7 \pm 1.2$ & $50.5 \pm 2.0$ & $44.3 \pm 3.4$ & Silty Clay \\
\hline Btk & 1 & $70-80$ & 0.2 & 8.2 & 7.3 & 4.6 & 0.3 & 57.9 & 8.4 & 0.6 & 0.9 & 4.2 & 46.7 & 49.1 & \\
\hline \multicolumn{16}{|c|}{$S^{4}(E / B t)=5.1$} \\
\hline \multicolumn{16}{|c|}{ Endocalcic Stagnic Albic Luvisols (Siltic, Abruptic, Cutanic, Epiloamic) (L2, midslope) } \\
\hline A & 1 & $6-13$ & 0.6 & 4.3 & 3.2 & 0 & 19.8 & 7.4 & 1.8 & 0.6 & 0.5 & 7.3 & 18.0 & 74.4 & \\
\hline E & 2 & $13-24$ & $0.5 \pm 0.1$ & $5.0 \pm 0.1$ & $3.5 \pm 0.1$ & 0 & $8.1 \pm 1.4$ & 6.1 & 0.9 & 0.4 & 0.3 & $3.6 \pm 0.2$ & $13.3 \pm 0.0$ & $82.9 \pm 0.3$ & Silt Loam \\
\hline $\mathrm{A}^{\prime}$ & 2 & $24-42$ & $0.6 \pm 0.1$ & $5.9 \pm 0.2$ & $4.5 \pm 0.2$ & 0 & $4.9 \pm 0.7$ & $14.9 \pm 3.2$ & $3.5 \pm 0.6$ & $0.5 \pm 0.1$ & $0.4 \pm 0.1$ & $1.7 \pm 0.2$ & $23.3 \pm 5.7$ & $75.1 \pm 5.5$ & Silt Clay Loam \\
\hline $\mathrm{Bt}$ & 4 & $42-70$ & $0.3 \pm 0.1$ & $6.5 \pm 0.4$ & $5.0 \pm 0.4$ & $2.7 \pm 1.3$ & $3.2 \pm 1.1$ & $24.9 \pm 6.0$ & $4.7 \pm 0.6$ & 0.6 & $0.7 \pm 0.2$ & $0.9 \pm 0.7$ & $50.6 \pm 7.4$ & $48.4 \pm 6.7$ & Silty Clav \\
\hline Btgk & 1 & $70-80$ & 0.2 & 7.9 & 7.1 & 5.8 & 0.4 & 35.9 & 4.8 & 0.6 & 0.8 & 2.4 & 49.2 & 48.4 & Siny Ciay \\
\hline \multicolumn{16}{|c|}{$\mathrm{S}(\mathrm{E} / \mathrm{Bt})=4.5$} \\
\hline \multicolumn{16}{|c|}{ Calcic Stagnic Greyzemic Epidystric Umbrisols (Siltic) (Um, toeslsope) } \\
\hline A & 2 & $10-24$ & 3.0 & $4.5 \pm 0.2$ & $3.3 \pm 0.1$ & 0 & $28.0 \pm 5.8$ & $16.4 \pm 1.8$ & $3.4 \pm 0.2$ & $0.8 \pm 0.1$ & 0.9 & $11.9 \pm 3.5$ & $27.1 \pm 1.2$ & $62.6 \pm 2.6$ & Silt Clay Loam \\
\hline $\mathrm{A}^{\prime}$ & 3 & $24-50$ & $1.6 \pm 0.4$ & $5.8 \pm 0.5$ & 4.8 & 0 & $10.3 \pm 3.8$ & $23.7 \pm 3.1$ & $2.6 \pm 0.8$ & 0.7 & 0.6 & $3.6 \pm 2.0$ & $38.8 \pm 10$ & $58.4 \pm 7.9$ & Silty Clay Loam/Silty Clay \\
\hline $\mathrm{A}^{\prime} / \mathrm{Bg}$ & 2 & $50-70$ & $0.3 \pm 0.1$ & $7.2 \pm 0.6$ & $5.6 \pm 0.4$ & 0 & $2.7 \pm 1.9$ & $25.4 \pm 3.1$ & $2.6 \pm 0.1$ & 0.7 & $0.8 \pm 0.2$ & $1.2 \pm 0.1$ & $44.0 \pm 1.7$ & $53.4 \pm 0.4$ & Silty Clay \\
\hline Bgk & 2 & $70-85$ & 0.2 & 8.2 & $6.3 \pm 0.1$ & 0.4 & 0.7 & $22.1 \pm 1.6$ & $2.3 \pm 0.5$ & $0.7 \pm 0.1$ & 0.6 & $0.9 \pm 0.8$ & $38.9 \pm 1.6$ & $60.3 \pm 2.4$ & Silty Clay \\
\hline
\end{tabular}

${ }^{1}$ Soil physical and chemical data are reported as the mean value of replicate analyses ( \pm 1 SD when $\left.n \geq 2\right) ;{ }^{2} \mathrm{n}-$ the number of soil samples collected at different depths for each horizon; ${ }^{3}$ SOC—-soil organic carbon; ${ }^{4} \mathrm{~S}$ - the coefficient of soil profile textural differentiation in respect to silt. 


\subsection{Phytolith Analysis}

\subsubsection{Endocalcic Stagnic Albic Luvisol (Siltic, Abruptic, Cutanic, Epiloamic) (Eluvial Position)}

The A horizon phytolith assemblage consisted of the phytoliths of dicotyledonous herbs, forest, and meadow grasses (the latter predominating), as well as of phytoliths of mosses and coniferous trees (Figures 2 and 3A). The charcoal phytoliths contributed up to $7 \%$.
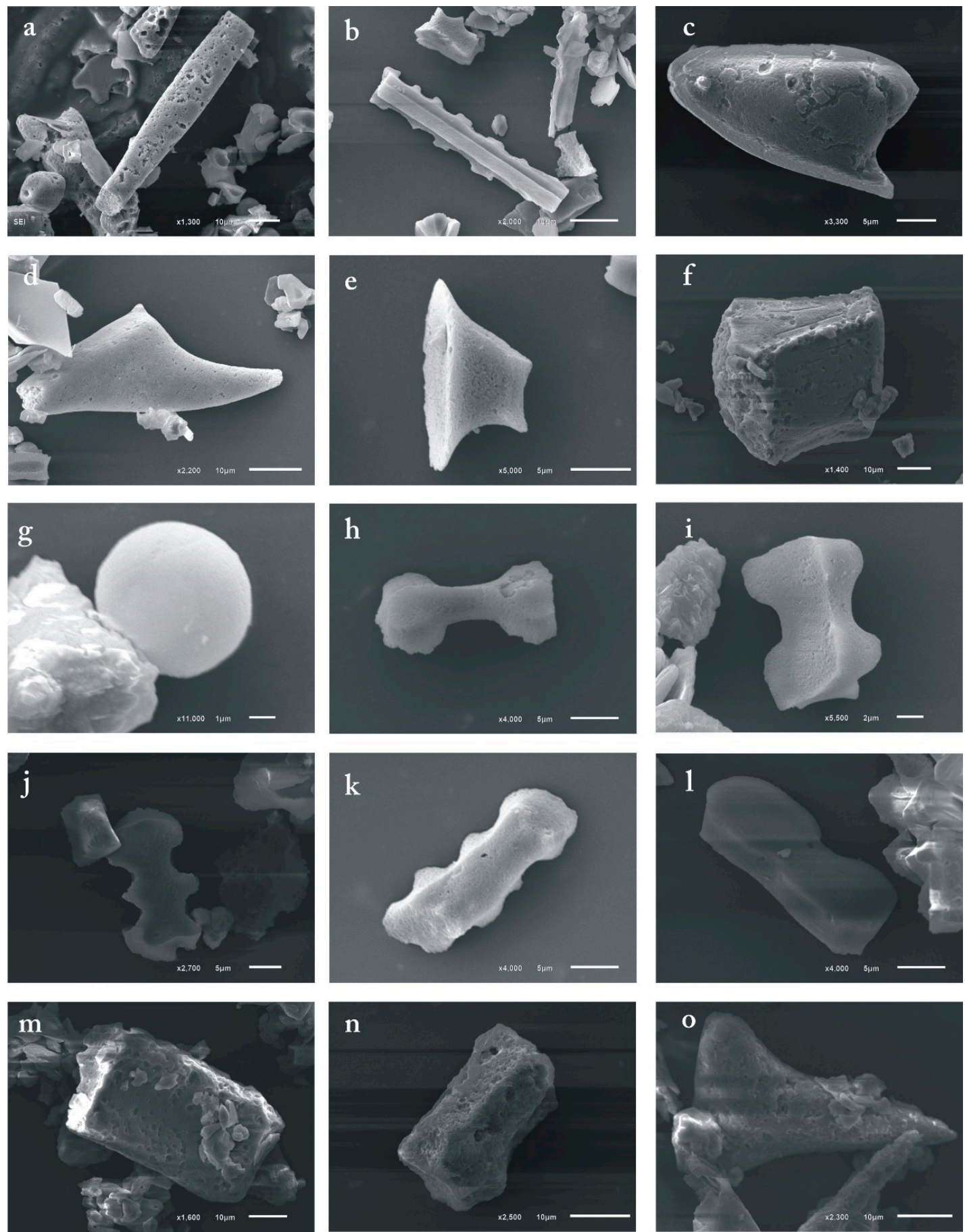

Figure 2. Micrographs of the phytolith types considered for this study: (a,b)-Elongate; (c) - Carinate lanceolate; (d)_Carinate conical; (e)-Rondel; (f)-Bulliform cuneiform; (g)-Globular psilate; $(\mathbf{h}, \mathbf{i})$-Bilobate; $(\mathbf{j}-\mathbf{l})$-Trapiziform polybate; $(\mathbf{m}, \mathbf{n})$-Cubic scrobiculate; $(\mathbf{o})$-Acicular hair cell. 
A

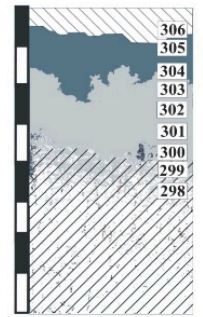

B

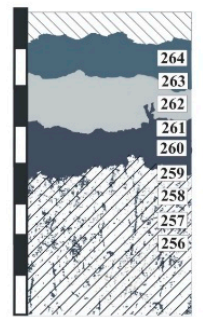

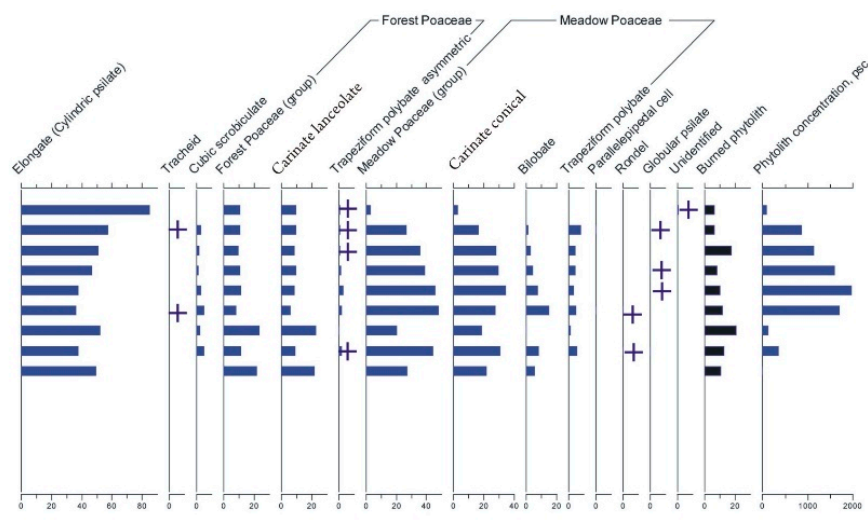
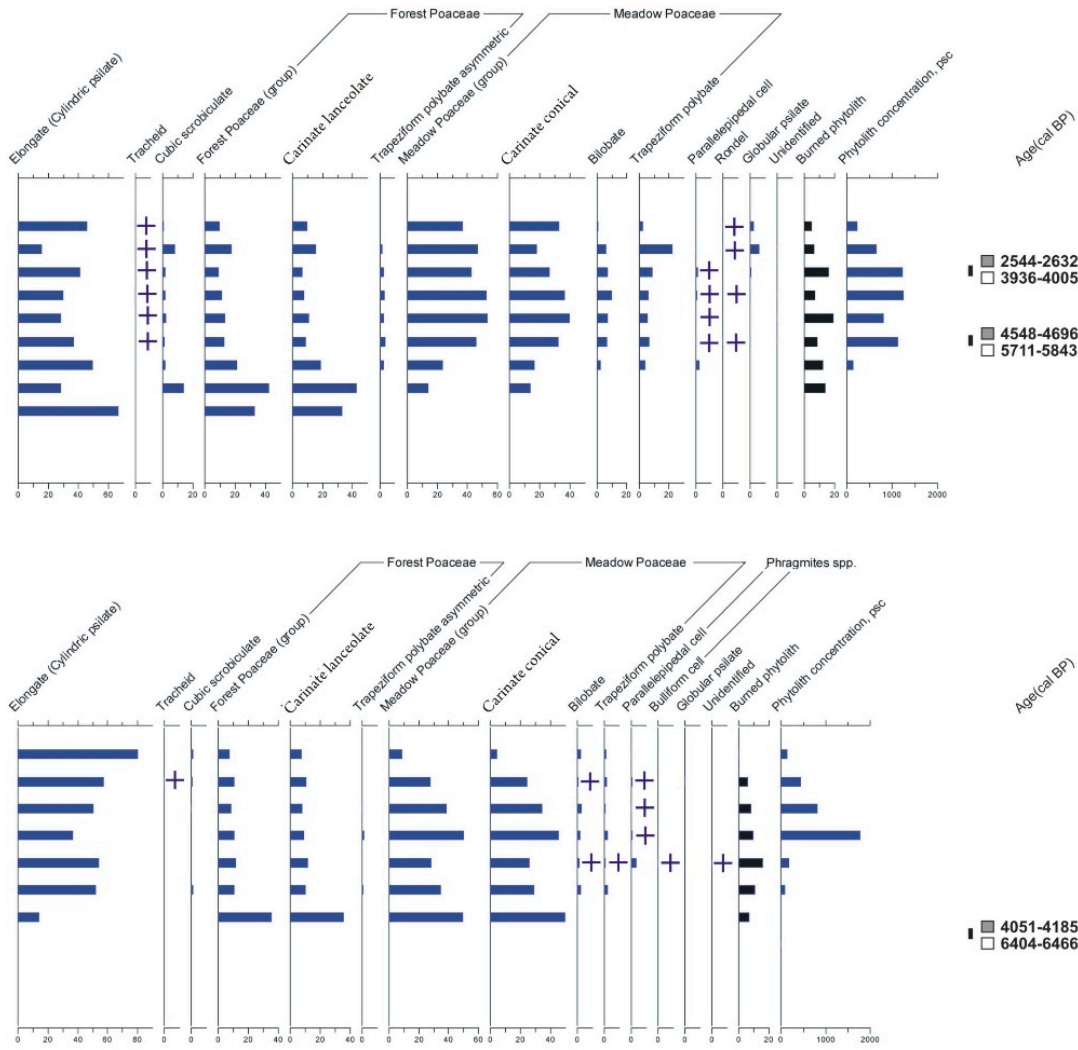

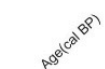

吕 $2031-2410$

㧽 $44220-5321$
C

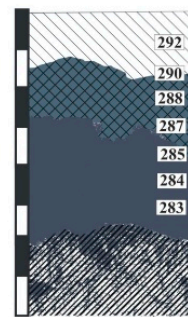

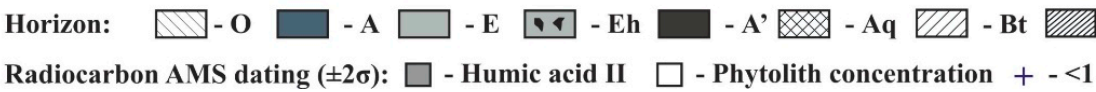
- A' - Aq $2 A$ - Bt

Figure 3. Soil phytolith profiles (percentage of the total content). Soils: (A)—Endocalcic Stagnic Albic Luvisols (Siltic, Abruptic, Cutanic, Epiloamic) on the hilltop; (B)-Endocalcic Stagnic Albic Luvisols (Siltic, Abruptic, Cutanic, Epiloamic) on the midslope; and (C)-Calcic Stagnic Greyzemic Epidystric Umbrisols (Siltic) on the toeslope.

The E horizon phytolith assemblage had the same phytolith composition, but with increased concentrations of some groups. The horizon upper border was found to have maximal (18\%) content of charcoal phytoliths, and the ratio of forest and meadow gramineous phytoliths shifts more four- to six-fold) towards the latter.

The second humus horizon, present in the form of dark-grey patches according to the morphological description, had increased phytolith concentration, with the ratio of forest and meadow gramineous phytoliths shifted towards the former ones. Phytoliths derived from the steppe grasses were found in the lower part of the horizon (1\%). 
According to phytolith analysis of the soil in the eluvial position, the start of the soil formation and its most active stage were related to the meadow stage, as evidenced by the dominance of meadow grasses' phytoliths over the forest grasses' ones. The tree stands of that stage had coniferous species during the entire soil formation process, with a certain influence of fires on phytocoenosis development and structure.

Presumably, the closest analogue of the second humus horizon in the eluvial position soil can be seen in (semi)hydromorphic soils (Calcic Stagnic Chernozem) in the forest-steppe zone.

\subsubsection{Endocalcic Stagnic Albic Luvisols (Siltic, Abruptic, Cutanic, Epiloamic) (Transit Position)}

The soil profile phytolith assemblage in the midslope site was found to be rather similar to the one in the hilltop site; that is, there were mostly forest and meadow gramineous phytoliths, the latter exceeding 3.5-3.8 times the former, thus dominating in the humus-eluvial part of the soil profile (Figure 3B).

However, large parallelepiped-like morphotypes of Phragmites spp. phytoliths are found in small quantities in the $\mathrm{E}, \mathrm{A}^{\prime}$, and the upper $\mathrm{A}^{\prime} / \mathrm{Bt}$ horizons (Figures $2 \mathrm{f}$ and $3 \mathrm{~B}$ ), proving more periodically humid environmental conditions. Coniferous phytoliths were found throughout the entire humus-eluvial part of the soil profiles, with their contribution increasing upward.

Thus, the presence of Phragmites-type bulliform phytoliths and cubic foveolar phytoliths suggested that vegetation progressed from the intrazonal meadow-mire or mired forest phytocenoses towards the automorphic coniferous forest. The soil was identified as most likely being Calcic Stagnic Chernozem.

\subsubsection{Calcic Stagnic Greyzemic Epidystric Umbrisols (Siltic) (Toeslope Site)}

The soil profile was found to have a phytolith assemblage similar to those in the hilltop and midslope catena sites, being, in this respect, closer to that in Endocalcic Stagnic Albic Luvisols in the midslope site than to the hilltop type, as meadow gramineous phytoliths dominated by three to five times over the forest gramineous phytoliths, and Phragmites-type phytoliths were detected in the Aq and $A^{\prime}$ horizons (Figures $2 \mathrm{f}$ and $3 \mathrm{C}$ ).

The phytolith assemblage profile in the toeslope site was similar to the profile in the midslope site, but Phragmites-type bulliform cell phytoliths were found throughout the entire $\mathrm{A}$ and $\mathrm{A}^{\prime}$ horizons, thus confirming the longer period of hydromorphic soil formation in the trans-accumulative position and the relatively later start of the lessivage and albic material formation compared to the soils in the higher positions of the catena. The second humus horizon should be considered a residual from the Spodic Chernic Gleysols.

\subsection{AMS ${ }^{14} \mathrm{C}$ Dating of the Eluvial and Humus Horizons}

The optical and electron micropscopy data and EDS analysis of phytolith surfaces (Figure 4) showed no additional organic matter that could have compromised the radiocarbon dating results.
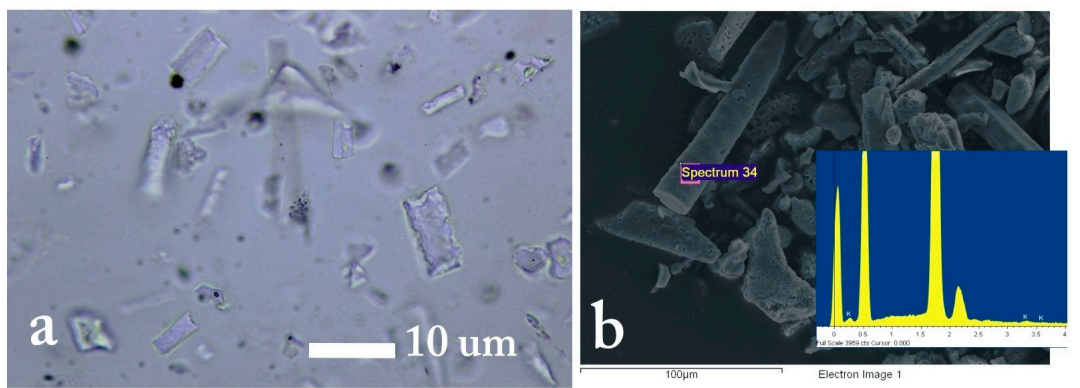

Figure 4. Images of phytoliths extracted from soils: (a)—Optical microscopy images of phytoliths; (b) - SEM image of phytoliths with EDS analysis of phytolith surface.

The radiocarbon dating results of phytolith-occluded carbon (PhytOC) and HAII are given in Table 3. 
Table 3. Results of AMS ${ }^{14} \mathrm{C}$ dating of the eluvial and second humus horizons.

\begin{tabular}{|c|c|c|c|c|c|c|c|c|}
\hline \multirow{2}{*}{ Lab. Number } & \multirow{2}{*}{ Horizon } & \multirow{2}{*}{ Depth, cm } & \multirow{2}{*}{ Carbon, \% } & \multirow{2}{*}{ Material } & \multirow{2}{*}{$\delta^{13} \mathrm{CPDB}, \%$} & \multirow{2}{*}{${ }^{14} \mathrm{C}$ Age Year BP } & \multicolumn{2}{|c|}{${ }^{14} \mathrm{C}$ Age Year BP, $2 \sigma$} \\
\hline & & & & & & & & Median \\
\hline \multicolumn{9}{|c|}{ Endocalcic Stagnic Albic Luvisols (Abruptic, Cutanic, Epiloamic, Siltic), hilltop } \\
\hline NSK-G1 & \multirow{2}{*}{ E } & \multirow{2}{*}{ 9-10 } & 1.14 & Phytolith & -32.1 & $3663 \pm 53$ & 2151-1902 & 2026 \\
\hline NSK-G8 & & & 47.34 & HAII & -29.6 & $3781 \pm 68$ & 2410-2031 & 2220 \\
\hline NSK-G3 & \multirow{2}{*}{ Eh } & \multirow{2}{*}{$29-30$} & 1.19 & Phytolith & -30.0 & $6301 \pm 26$ & $5321-5220$ & 5270 \\
\hline NSK-G6 & & & 41.34 & HAII & -31.3 & $5700 \pm 25$ & $4600-4462$ & 4531 \\
\hline \multicolumn{9}{|c|}{ Endocalcic Stagnic Albic Luvisols (Abruptic, Cutanic, Epiloamic, Siltic), midslope } \\
\hline NSK-G4 & \multirow[b]{2}{*}{ E } & \multirow{2}{*}{$19-20$} & 0.89 & Phytolith & -28.6 & $5154 \pm 32$ & $4005-3936$ & 3970 \\
\hline NSK-G9 & & & 30.53 & HAII & -31.2 & $4051 \pm 23$ & $2632-2544$ & 2588 \\
\hline NSK-G2 & \multirow{2}{*}{$\mathrm{A}^{\prime}$} & \multirow{2}{*}{$34-35$} & 1.43 & Phytolith & -30.4 & $6883 \pm 32$ & $5843-5711$ & 5777 \\
\hline NSK-G7 & & & 47.97 & HAII & -26.7 & $5775 \pm 25$ & $4696-4548$ & 4622 \\
\hline \multicolumn{9}{|c|}{ Calcic Stagnic Greyzemic Epidystric Umbrisols (Siltic), toeslope } \\
\hline NSK-G5 & & & 3.35 & Phytolith & -29.4 & $7475 \pm 27$ & $6466-6404$ & 6435 \\
\hline NSK-G10 & $A^{\prime}$ & $59-60$ & 37.70 & HAII & -29.3 & $5311 \pm 25$ & 4185-4051 & 4118 \\
\hline
\end{tabular}


The sample, collected from the lower boundary of the A' horizon within Calcic Stagnic Greyzemic Epidystric Umbrisols had PhytOC dated as 6404-6466 cal year BP (median 6435 year cal BP) and humic acid dated as 4051-4185 cal year BP (median 4118 year cal BP) (Figure 5). The difference between the dates exceeded 2300 year and most likely results from the different rates of organic carbon rejuvenation in the soil and PhytOC. The carbon contained in different humic acid fractions, which is the most resistant fraction in HAII under increased biochemical activity and lessivage, is rejuvenated, thus decreasing the radiocarbon dates [45]; conversely, the carbon occluded in phytoliths is preserved, since it is subject to a much less aggressively destructive soil-forming environment.

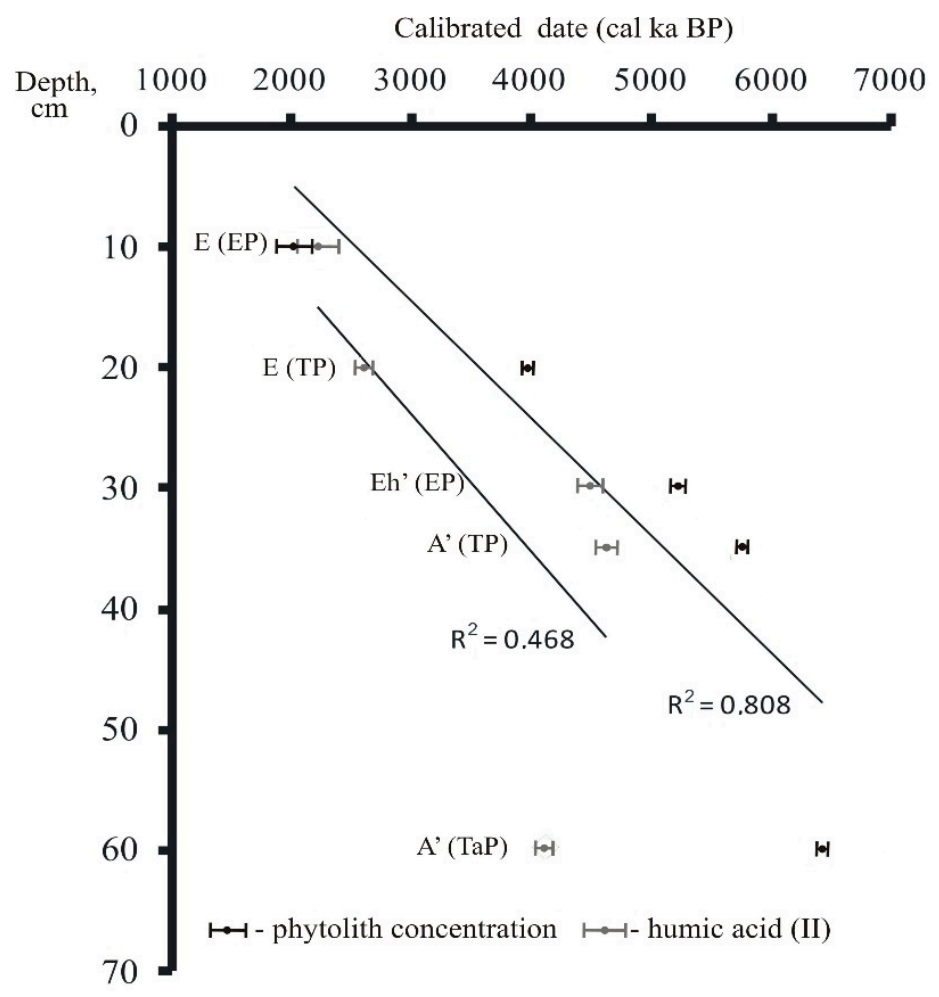

Figure 5. AMS radiocarbon dating results, with an uncertainty of $\pm 2 \sigma$ for phytolith concentration and humic acid (II) and age-depth and age-horizon relationships. Catena sites: EP—hilltop, TP—midslope, and $\mathrm{TaP}$ - toeslope.

The samples taken at the lower border of the second humus horizons of the hilltop and midslope sites were of a close PhytOC age: 5321-5220 cal year BP (median 5270 year cal BP) and 5843-5711 cal year BP (median 5777 year cal BP), respectively. If the difference in $5 \mathrm{~cm}$ between sample depths is taken into consideration, then the relative difference of 500 year between the radiocarbon dates can be discarded, and the samples can therefore be considered to have been formed synchronically. The same is true for the HAII radiocarbon dates, which were determined as 4600-4462 cal year BP (median 4531 year cal BP) for Eh horizons and 4696-4548 cal year BP (median 4622 year cal BP) for the A' horizons. However, the difference between the PhytOC and HAII radiocarbon dates exceeds 1000 year.

Comparison of the radiocarbon date differences in samples from the lower border of the second humus horizon of soils in the different catena sites showed that the carbon rejuvenation rate in HAII was almost 2.5 times higher in hilltop and midslope sites than in the toeslope site.

In the sample taken from the eluvial horizon of the midslope site soil, the PhytOC radiocarbon date was determined as 4005-3936 cal year BP (median 3970 year cal BP), whereas the date for HAII was estimated as 2632-2544 cal year BP (median 2588 year cal BP), the difference being ca. 1400 year. This confirms the process of carbon rejuvenation both in soil and in phytoliths, the rate being slower in phytolith-occluded carbon compared to soil organic carbon. 
In the sample taken from the E horizon of the eluvial position soil, the PhytOC and HAII radiocarbon dates were rather close, i.e., 2151-1902 cal year BP (median 2026 year cal BP) and 2410-2031 cal year BP (median 2220 year cal BP), respectively, with the difference being approximately 200 year.

As Table 3 and Figure 5 show, soil phytolith profiles are rather resistant to transformation, as can be concluded from their close radiocarbon dates of PhytOC from the second humus horizons in the different catena positions, namely, 6.5-5.3 years cal BP. Therefore, soil phytolith concentrations and phytolith assemblages should be considered synchronic to the dark-humus Mid-Atlantic stage of soil formation.

Recent studies investigating sources of PhytOC and assessing phytolith potential for radiocarbon dating showed multiple sources for PhytOC [46,47]. Some researchers established that one of the PhytOC sources may be soil carbon, which significantly decreases the age of recurrent plants' phytoliths. However, to establish the starting date of soil formation, the use of phytoliths from soil samples taken at the lower border of the humus horizon is justified, despite it being a source of carbon in phytoliths.

The PhytOC radiocarbon date would be especially close to the start of humus formation in those cases when soil organic carbon, which undergoes rejuvenation, is analysed in different HA fractions.

In addition, the radiocarbon date regression with soil depth $\left(R^{2}=0.808\right.$, Figure 5) in all catena positions allows the assumption that soil carbon was not the leading source of PhytOC; if this had been the case, the profile distribution would have been more even with no explicit regression pattern. The main source of phytolith profile rejuvenation is provided by new phytoliths becoming mixed into the soil due to plant litter decomposition and by their subsequent translocation down towards the lower border of the eluvial portion of the soil profile [48].

Thus, different materials used for radiocarbon dating were shown to rejuvenate with depth, but the depth and the rate of the new carbon input depends on the carbon-preserving environment and the rate of soil textural differentiation, resulting in the redistribution of organic matter downwards. The largest degree of rejuvenation manifested in the soil in the hilltop site, whereas that of the toeslope showed the lowest degree of rejuvenation. The phytolith-occluded carbon was found to be more recalcitrant to rejuvenation than the soil organic carbon.

\section{Conclusions}

The combined use of radiocarbon dating, phytolith analysis, and conventional soil analysis methods to study co-evolved soils with complex organic matter profiles revealed the changes in the soil formation environment and the corresponding shifts in soil types.

The topographical divergence of soil phytolith profiles reflects the relief effect on the development of specific soil type combinations, accounting for the major elements of the regional mid-Holocene soil cover. The leading elementary soil-forming processes were humus accumulation and hydrogenic accumulation of calcium carbonates.

In the hilltop site in Endocalcic Stagnic Albic Luvisols, the evolutionary changes were shown by the shift from the meadow phytocenosis (Calcic Stagnic Chernozem) to the forest phytocenosis, i.e., from the soddy type of soil formation to textural differentiation of the soil profile with albic material formation.

In the midslope site, the environment was more humid from the start, favouring a phytocenosis with features of the meadow-mire. The shift from the meadow-mire environment (with Spodic Chernic Gleysols) to the forest type with clay illuviation was gradual, occurring via the meadow stage with Calcic Stagnic Chernozem.

In the toeslope site (Calcic Stagnic Greyzemic Epidystric Umbrisols), the meadow-mire stage (with Spodic Chernic Gleysols) was succeeded by the forest stage of soil formation.

Comparison of the soil radiocarbon date profiles, obtained using different organic carbon containing material, revealed a higher recalcitrance to rejuvenation of phytolith-occluded carbon compared to humic acid carbon. Carbon rejuvenation of different materials depends on the soil textural differentiation along a particular catena. 
Author Contributions: D.A.G., S.V.L. and N.V.K. performed the fieldwork and soil sampling, conceived and designed the experiments and wrote the paper; D.A.G. and N.V.K. performed phytolith analysis, made phytolith and humic acid preparations for AMS-dating, studied physical and chemical soil proprieties. All together we discussed the obtained data and corrected the text.

Funding: This research was funded by the Russian Foundation of Basic Research (project No. 16-34-00325).

Acknowledgments: We thank Natalia Naumova for correcting the English language.

Conflicts of Interest: The authors declare no conflict of interest. The funding sponsors did not take part in the design of the study; in the collection, analyses, or interpretation of data; in the writing of the manuscript; or in the decision to publish the results.

\section{References}

1. Dukarev, A.G.; Pologova, N.N. Soils with complex organic profiles on the Vasyugan plain. Eurasian Soil Sci. 2011, 44, 480-492. [CrossRef]

2. Lashchinsky, N.N.; Korolyuk, A.Y. Syntaxonomy of zonal dark-coniferous forests of southern taiga of the West Siberian plain and of humid low-mountains of the Altai-Sayan mounain region. Veg. Russia 2015, 26, 85-107, (In Russian, Summary in English).

3. Gadzhiev, I.M. Evolution of Taiga Soils in Western Siberia; Nauka: Novosibirsk, Russia, 1982; pp. 1-455. (In Russian)

4. Dyukarev, A.G. Landscape and Dynamic Aspects of Taiga Soil Formation in Western Siberia; NTL Publishing: Tomsk, Russia, 2005; pp. 1-284. (In Russian)

5. Ponomareva, V.V.; Tochelnikov, Y.S. Some data on the composition and properties of humus and the genesis of soil with the second humus horizon of the southern taiga of Western Siberia. Proc. Inst. Geogr. Sib. Far East 1968, 20, 23-32. (In Russian)

6. Nechaeva, E.G.; Laivinish, M.I. Spatial distribution patterns of podzolic soils with the second humus horizon. Proc. Inst. Geogr. Sib. Far East 1970, 25, 38-48. (In Russian)

7. Budina, L.P.; Erokhina, A.A. Genetic features of sod-podzolic gleysolic cold soils with second humus horizon of Krasnoyarsk Kray. Pochvovedenie 1969, 10, 13-28. (In Russian)

8. Dobrovolsky, G.V.; Afanaseva, T.V.; Vasilenko, V.I.; Remezova, G.L. About genesis and geography of soils of Tomsk Priobje. Pochvovedenie 1969, 10, 3-12. (In Russian)

9. Afanasyeva, T.V.; Remezova, G.L. On relict signs of secondary podzolic soils of the southern taiga of Western Siberia. Moscow State Univ. Bull. Ser. 15 Soil Sci. 1974, 1, 118-123.

10. Ufimtseva, K.A. Soils of the Southern Taiga Zone of the West Siberian Plain; Kolos: Moscow, Russia, 1974; pp. 1-203. (In Russian)

11. Karavaeva, N.A. Genesis and evolution of the second humus horizon in the soils of southern taiga of Western Siberia. In Pedogenesis and Weathering in Humid Landscapes; Targulian, V.O., Ed.; Nauka: Moscow, Russia, 1978; pp. 133-157. (In Russian)

12. Gavrilov, D.A.; Golyeva, A.A. Microbiomorphic research of soils with the second humus horizon of the West Siberian southern taiga subzone (Russia). Tomsk State Univ. J. Biol. 2014, 2, 5-22, (In Russian, Summary in English). [CrossRef] [PubMed]

13. Dobrovolsky, G.V.; Afanasyeva, T.V.; Vasilenko, V.I. On the age and relict features of soils in the Tomsk $\mathrm{Ob}$ region. In Materials for the Symposium 4th Meetings of Geographers of Siberia and the Far East; Nauka: Novosibirsk, Russia, 1969; pp. 117-119. (In Russian)

14. Tochelnikov, Y.S. To the characteristic of the absolute age of the second humus horizon of sod-podzolic soils of Western Siberia. Proc. Acad. Sci. SSSR Ser. Geol. 1970, 191, 1151-1152. (In Russian)

15. Jones, R.L.; Beavers, A.H. Aspects of caternary and depth distribution of opal phytoliths in Illinois soils. Soil Sci. Soc. Am. Proc. 1964, 28, 413-416. [CrossRef]

16. Bobrova, E.; Bobrov, A. Phytoliths in soils: Species composition, distribution along a soil profile, and value as environmental indicators. In Monografías del Centro de Ciencias Medioambientales, CSCI (4), The State of-the-Art of Phytholits in Soils and Plants; Pinilla, A., Juane Tresseras, J., Machado, M.J., Eds.; CSCI: Madrid, Spain, 1997; pp. 5-13. 
17. Golyeva, A.A. Content and distrubution of phytoliths in the main types of soils in Eastern Europe. In Monografias del Centro de Ciencias Medioambientales, CSCI (4), The State of-the-Art of Phytholits in Soils and Plants; Pinilla, A., Juane Tresseras, J., Machado, M.J., Eds.; CSCI: Madrid, Spain, 1997; pp. 15-22.

18. Golyeva, A.A. Biomorphic analysis as a part of soil morphological investigations. Catena 2001, 43, $217-230$. [CrossRef]

19. Golyeva, A.A.; Alexandrovskiy, A.L.; Tselishcheva, L.K. Phytolithic analysis of Holocene paleosoils. Eurasian Soil Sci. 1995, 27, 46-56.

20. Golyeva, A.A.; Alexandrovskiy, A.L. The application of phytolith analysis for solving problems of soil genesis and evolution. Eurasian Soil Sci. 1999, 32, 884-891.

21. Kamanina, I.Z. Phytolits data analysis of soils of different landscape zones. In Monografías del Centro de Ciencias Medioambientales, CSCI (4), The State of-the-Art of Phytholits in Soils and Plants; Pinilla, A., Juane Tresseras, J., Machado, M.J., Eds.; CSCI: Madrid, Spain, 1997; pp. 23-32.

22. Kamanina, I.Z. Accumulation of phytoliths in Southern Taiga soils of different age. In Monografías del Centro de Ciencias Medioambientales, CSCI (4), The State of-the-Art of Phytholits in Soils and Plants; Pinilla, A., Juane Tresseras, J., Machado, M.J., Eds.; CSCI: Madrid, Spain, 1997; pp. 45-47.

23. Kamanina, I.Z.; Shoba, A. The phytoliths analysis applied to soils of complex formation and paleosoils. In Monografias del Centro de Ciencias Medioambientales, CSCI (4), The State of-the-Art of Phytholits in Soils and Plants; Pinilla, A., Juane Tresseras, J., Machado, M.J., Eds.; CSCI: Madrid, Spain, 1997; pp. 33-43.

24. Peto, Á. Studying modern soil profiles of different landscape zones in Hungary: An attempt to establish a soil-phytolith identification key. Quat. Int. 2013, 287, 149-161. [CrossRef]

25. Calegari, M.R.; Lopes Paisani, S.D.; Cecchet, F.A.; Ewald, P.; Osterrieth, M.L.; Paisani, J.C.; Pontelli, M.E. Phytolith signature on the Araucarias Plateau-Vegetation change evidence in Late Quaternary (South Brasil). Quat. Int. 2016, 434, 1-12. [CrossRef]

26. Silva Neto, E.C.D.; Calegari, M.R.; Pereira, M.G.; Maranhão, D.D.C.; Schiavo, J.A.; Fontana, A.; Fernandes, J.C.F. Phytoliths as indicators of pedogenesis and paleoenvironmental changes in Spodosols of the state of Rio de Janeiro, Brazil. Sci. Total Environ. 2018, 636, 1070-1080. [CrossRef] [PubMed]

27. Fisher, R.F.; Newell Bourne, C.; Fisher, W.F. Opal phytoliths as an indicator of the floristics of prehistoric grasslands. Geoderma 1995, 68, 243-255. [CrossRef]

28. Piperno, D.R. Phytoliths: A Comprehensive Guide for Archaeologists and Paleoecologists; Alta Mira Press: Lanham, MD, USA, 2006; pp. 1-238.

29. Piperno, D.R. Quaternary environmental history and agricultural impact on vegetation in Central America. Ann. Mo Bot. Gard. 2006, 93, 274-296. [CrossRef]

30. Electronic Version of the National Atlas of Soils of the Russian Federation. Available online: https:/ / soilatlas. $\mathrm{ru} /$ (accessed on 20 October 2018). (In Russian)

31. Golyeva, A.A. Phytoliths and Their Information Role in Natural and Archeological Objects; Polteks: Moscow, Russia; Syktyvkar, Russia; Elista, Russia, 2001; pp. 1-140. (In Russian)

32. IUSS Working Group WRB 2014. World Reference Base for Soil Resources 2014. International Soil Classification System for Naming Soils and Creating Legends for Soil Maps; World Soil Resources Reports No. 106; FAO: Rome, Italy, 2014; pp. 1-192.

33. FAO. Guidelines for Soil Description, 4th ed.; FAO: Rome, Italy, 2006; pp. 1-97.

34. Kachinskiy, N.A. The Physics of Soils; Vysshaya Shkola Publishers: Moscow, Russia, 1965; pp. 1-321. (In Russian)

35. Skjemstad, J.O.; Baldock, J.A. Total and Organic Carbon. In Soil Sampling and Methods of Analysis, 2nd ed.; CRC Press: Boca Raton, FL, USA, 2008; pp. 225-237.

36. Hendershot, W.H.; Lalande, H.; Duquette, M. Ion Exchange and Exchangeable Cations. In Soil Sampling and Methods of Analysis, 2nd ed.; CRC Press: Boca Raton, FL, USA, 2008; pp. 197-208.

37. Theory and Practice Chemical Analysis of Soils; Vorobyova, L.F. (Ed.) GEOS: Moscow, Russia, 2006; 400p. (In Russian)

38. Chichagova, O.A. Radiocarbon Dating of Soil Humus: Its Method and Use in Pedology and Paleogeography; Nauka: Moscow, Russia, 1985; pp. 1-158.

39. Zuo, X.; Lu, H.; Zhang, J.; Wang, C.; Sun, G.; Zheng, Y. Radiocarbon dating of prehistoric phytoliths: A preliminary study of archaeological sites in China. Sci. Rep. 2016, 6, 26769. [CrossRef] [PubMed] 
40. Bronk Ramsey, C. Radiocarbon calibration and analysis of stratigraphy: The OxCal program. Radiocarbon 1995, 37, 425-430. [CrossRef]

41. Piperno, D.R. Phytolith Analysis: An Archaeological and Geological Perspective; Academic Press: San Diego, CA, USA, 1988; pp. 1-280.

42. Golyeva, A.A. Various phytolith types as bearers of different kinds of ecological information. In Plant, People and Places e Recent Studies in Phytolith Analysis; Madella, M., Debora, Z., Eds.; Oxbow: Oxford, UK, 2007; pp. 196-208.

43. Golyeva, A.A. Microbiomorphic Analysis as a Tool for Natural and Anthropogenic Landscape: Genesis, Geography, Information; URSS: Moscow, Russia, 2008; pp. 1-256. (In Russian)

44. Madella, M.; Alexandre, A.; Ball, T. International Code for Phytolith Nomenclature 1.0. Ann. Bot. 2005, 96, 253-260. [CrossRef] [PubMed]

45. Alexandrovsliy, A.L.; Chicagova, O.A. Radiocarbon age of Holocene paleosols of the East European forest-steppe zone. Catena 1998, 34, 197-207. [CrossRef]

46. Santos, G.M.; Alexandre, A.; Southon, J.R.; Treseder, K.K.; Corbineau, R.; Reyerson, P.E. Possible source of ancient carbon in phytolith concentrates from harvested grasses. Biogeosciences 2012, 9, 1873-1884. [CrossRef]

47. Reyerson, P.E.; Alexandre, A.; Harutyunyan, A.; Corbineau, R.; Martinez De La Torre, H.A.; Badeck, F.; Cattivelli, L.; Santos, G.M. Unambiguous evidence of old soil carbon in grass biosilica particles. Biogeosciences 2016, 13, 1269-1286. [CrossRef]

48. Fishkis, O.; Ingwersen, J.; Lamers, M.; Denysenko, D.; Streck, T. Phytolith transport in soil: A field study using fluorescent labeling. Geoderma 2010, 157, 27-36. [CrossRef]

(C) 2018 by the authors. Licensee MDPI, Basel, Switzerland. This article is an open access article distributed under the terms and conditions of the Creative Commons Attribution (CC BY) license (http:// creativecommons.org/licenses/by/4.0/). 